\title{
Erratum to: Popular Media in Kenyan History
}

\author{
George Ogola
}

The following references have been added in the printed version in Chapters $1,2,3,5,6,7$, and 8 .

Chapter 1 (pages 20-21)

Beti, Mongo. 1958. Mission to Kala. Nairobi: Heinemann Educational Publications.

Hertzler, Joyce. 1970. Laughter: A Socio-Scientific Analysis. New York: Exposition Press.

Street, John. 1997. Politics and Popular Culture. Cambridge: Polity Press.

Taylor, Pegi. 2002. Creative Nonfiction. The Writer 15(2): 29-33.

DOI 10.1007/978-3-319-49097-7_1

\section{Chapter 2 (pages 36-37)}

Achebe, Chinua. 1958. Things Fall Apart. London: Heinemann.

Bryce, Jane. 1997. Women and modern African fiction. Readings in African Popular Culture, 118-124. Bloomington and Indiana: Indiana University Press.

Etherton, Michael. 1982. The Development of African Drama. New York: African Publishing Company.

Lindfors, Bernth. 1991. Popular Literatures in Africa. Trenton, NJ: Africa World Press.

Sparks, Colin. 1992. Popular Journalism: Theories and Practice. In Journalism and Popular Culture, edited by Dahlgren Peter and Colin Sparks, 25-44. London: Sage. 
Wildhaber, Robert. 1965. A Bibliographical Introduction to American Folklore. New York Folklore 21(4): 259.

DOI 10.1007/978-3-319-49097-7_2

Chapter 3 (pages 51-52)

Ogola, George. 2010. 'If You Rattle a Snake, Be Prepared to Be Bitten': Popular Culture, Politics and the Digital Public Sphere and the Kenyan News Media. In Popular Media, Democracy and Development in Africa, ed. Herman Wasserman, 123-136. London: Routledge.

Said, Edward. 1994. Culture and Imperialism. London: Vintage.

DOI 10.1007/978-3-319-49097-7_3

Chapter 5 (pages 87-88)

Kitzinger, Jenny. 2000. Media Templates: Patterns of Association and the Reconstruction of Meanings over Time, in Media, Culture and Society, 22(1): 61-84.

Ogot, Grace. 1983. Miaha. Nairobi: Heinemann Educational Books.

DOI 10.1007/978-3-319-49097-7_5

\section{Chapter 6 (pages 117-118)}

Kenyatta, Jomo. 1938. Facing Mount Kenya. London: Secker and Warburg.

Lonsdale, John. 1981. States and Social Processes in Africa: A Historiographical Survey. African Studies Review 24: 139-225.

Markakis, John. 1974. Ethiopia: Anatomy of a Traditional Polity: Oxford University Press.

Sklar, Richard. 1979. The Nature of Class Domination in Africa. The Journal of Modern African Studies. 17.04: 531-552.

Wicke, Peter. 1992. The Role of Rock Music in the Political Disintegration of East Germany. Popular Music and Communication, ed. Lull, James. ed, 196-206. Newbury Park: Sage.

Young, Tom. 2003. Readings in African Politics. Bloomington and Indianapolis: Indiana University Press.

Eyoh, Dickson. 1999. Community, Citizenship, and the Politics of Ethnicity in Post-colonial Africa. In Sacred Spaces and Public Quarrels: African Cultural and Economic Landscapes, ed. Ezekiel Kalipeni and Tiyambe Zeleza, 271-300. Asmara: Africa World Press.

DOI 10.1007/978-3-319-49097-7_6

\section{Chapter 7 (pages 138-139)}

Haugerud, Angelique. 1995. The Culture of Politics in Modern Kenya. Cambridge: Cambridge University Press.

Kariuki, James. 1996. 'Paramoia': Anatomy of a Dictatorship in Kenya. Journal of Contemporary African Studies 14(1): 69-86. 
Corten, Andre and Marshall-Fratani Ruth (eds). 2001. Between Babel and Pentecost: Transnational Pentecostalism in Africa. London: Hurst and Company.

DOI 10.1007/978-3-319-49097-7_7

Chapter 8 (pages 162-164)

Fiske, John. 1987. Television Culture. London: Routledge.

Bakhtin Mikhal. 1981. The Dialogic Imagination. Translated by Caryl Emerson and Michael Holquist. Austin: University of Texas Press.

Werbner, Richard (ed.). 1998. Memory and the Postcolony: African Antbropology and the Critique of Power. London: Zed Books Ltd.

DOI 10.1007/978-3-319-49097-7_8

The updated online version of the original book can be found at http://dx.doi.org/10.1007/978-3-319-49097-7 